SHS Web of Conferences 10, 00015 (2014)

DOI: $10.1051 /$ shsconf/20141000015

C Owned by the authors, published by EDP Sciences, 2014

\title{
Prerequisites for prevention of aggressive parental behaviour with their children
}

\author{
B. Kairiene
}

Mykolas Romeris University, Lithuania

\begin{abstract}
Aggressive behaviour of parents with children remains an urgent problem despite the changing attitude towards the child in the family and society. It is a complex legal, educational, medical, psychological, and social problem that requires systematic interdisciplinary outlook when seeking preventive possibilities to solve the problem. Legal, educational and psychosocial insights of the phenomenon are examined in the article. Legal prerequisites are linked to establishment of aggressive behaviour criteria - purposefulness and harm which determine child victim status and at the same time possibilities to help him. Educational prerequisites are based on the interaction of the parent and the child that is always educational, hence they have to be based on the equivalence of the interaction of the participants and respect for person's dignity. Psychosocial prerequisites are linked to child empowerment, and that is possible at all levels of prevention in order to use possibilities of the child to actively participate while implementing and defending his own rights and interests.
\end{abstract}

\section{Introduction}

Today, despite a very rapid development of science and technologies, mankind is not successful in getting rid of aggression in interpersonal relationships, which manifests itself in a variety of forms and in different social relationships. Aggressive parental behaviour with their children is not a new phenomenon in the world, however, earlier such behaviour with children was considered as a matter of course and tolerable, today it is identified as violent, coercive, harmful, disturbing mental and social development of the child, infringing the rights of the child, inconsistent with child's interests and the like.

One of the material changes related to the change of status of the child in the family and society took place when the United Nations adopted the Convention of the Rights of the Child (Convention on the Rights of the Child, 1989). Legal basis to evaluate the behaviour of adults with the child emerged, whereas the obligations of States towards the international community showed the recognition of the value of the child and gave an opportunity to take resolute action to change the status of the child. It has been recognized that the status of the child is the basis for society's survival, development and wellbeing (Noh, Wan Talaat, 2012) however, despite progress in the area of child protection and help towards him, it is still possible to consider only legal changes in the child's status - there is still a great gap between legal documents that define ideal conditions for children on the macro-level of the government

This is an Open Access article distributed under the terms of the Creative Commons Attribution License 4.0, which permits unrestricted use, distribution, and reproduction in any medium, provided the original work is properly cited. 
and the implementation on the micro-level of communities and families (Hundeide, Armstrong, 2011): the rights of the child are infringed (Summary of..., 2006; Shapiro-Mendoza et al., 2009; Weber et al., 2009), children are pointed out as the most vulnerable social group of the society (Pritchard, 2004; Brock, 2005; Pritchard, Sayers, 2008), aggressive behaviour of parents with their children remains an urgent issue in all the world (Miller-Perrin, Perrin, Kocur, 2009; Pritchard, Williams, 2010; Annerbäck et al., 2012).

Aggressive parental behaviour with their child is a complex issue that combines both psychological and educational and legal and medical aspects. From a legal perspective aggressive parental behaviour is identified as an infringement of child's rights or a criminal deed, from a psychosocial perspective it is evaluated by taking into account the consequences of the expression of the phenomenon on the child development, from a medical perspective it is evaluated by taking into account injuries incurred by the child, from an educational perspective it is evaluated by taking into account the destructiveness of educative intercourse when functioning of the family broke. One aspect of phenomenon is underlined more often in scientific literature: aggressive parental behaviour with their children as infringements of the rights of the child (Sagatys, 2008; Freeman, 2010), psychological characteristics of the members of intercourse, factors that influence the phenomenon and consequences (Gershoff, 2002; Annerbäck et al., 2012), more rarely educational problem of the phenomenon is emphasized (Simons, Wurtele, 2010), but systematic point of view that covers various aspects of the expression of the phenomenon and prevention is lacking. The complexity of the problem of aggressive parental behaviour with their children requires systematic interdisciplinary point of view when looking for possibilities of preventive solution of the phenomenon.

The object of the research is prerequisites for prevention of aggressive parental behaviour with their children.

The purpose of the research: to reveal prerequisites for prevention on the basis of the systematic point of view towards the phenomenon of aggressive parental behaviour with their children.

Tasks:

1. to reveal legal prerequisites for prevention of aggressive parental behaviour;

2. to reveal educational prerequisites for prevention of aggressive parental behaviour;

3. to reveal psychosocial prerequisites for prevention of aggressive parental behaviour. Methods: analysis of the sources of literature, abstracts, inductive-deductive.

\section{Legal prerequisites for prevention of aggressive parental behaviour with their children}

Legal prerequisites for prevention of aggressive parental behaviour with their children are linked to implementation of the child's rights and interests in the family. Family functioning is protected by the state - nobody has a right to intrude into family life without a valid reason. In those cases when the child experiences aggressive parental behaviour in many cases it is possible to help him by intervening into family life through application of legal and other remedies, therefore the precision of the definition of a situation under examination is necessary.

The protection of the child who has experienced aggressive parental behaviour begins then when the child is identified as a victim. However from a victimisation perspective the status of such child is not defined until now. Specificity of the relationship between parents and children, the expression of aggressive behaviour and the character of the caused damage determine that only in some cases child's experience gets legal assessment, and aggressive behaviour with the child can be assessed as an event of victimisation. The problem of children victimisation is determined by the fact that the majority of children victimisation cases remain unknown (Finkelhor et al., 2012), there is still no sufficient attention 


\section{Int. Conf. SOCIETY. HEALTH. WELFARE.}

to a child - victim when a victimisation case is found, whereas the idea of justice is based on aiming to detect a criminal deed and punish an offender.

The condition of the victim gets more complicated when he/she is the child, whereas the criminal deed is committed by his parents. If victimisation occurs in the family, there are no other source of information but participants of the interaction, and the initial stage of observation of aggressive behaviour, when it is possible to help the child and take preventive measures, is often very belated or the event remains unknown at all. It is difficult to establish and reveal such cases, because it is related to the intrusion of law enforcement agencies into private family life, by infringing family autonomy or evasion and inability of agencies to solve conflicts (Uscila, 2003).

The United Nations Convention on the Rights of the Child mentions the term of a child victim - Member States take all necessary measures to help the child that became the victim of the negligence, exploitation, abuse, torture or other cruel or inhumane behaviour that humiliates dignity, or punishment and armed conflicts to recuperate physically and psychologically and get reintegrated socially (Convention on the Rights of the Child, 1989). According to the definition of the Convention, the State guaranteed protection to the child is linked to the status of the victim. So the problem of the definition of the victim is encountered: on the basis of what indications the child can be identified as the victim; it is sufficient only to establish actions taken against the child. In the latter case the criteria should be clearly identified regarding to what actions are called aggressive. Should there the consequences of such actions be noted as well? Then such consequences have to be established, too.

The problem lies in the fact that consequences of aggressive actions may disappear (for example, bruise) or it is difficult to establish them (for example, in the case of psychological aggression), the question then arises: will we be able to identify the child as the victim only on the basis of established actions that were taken against him? Even if the consequences have been established, there is a need to prove that the consequences arouse due to the taken aggressive actions. In the case of physical aggression, if the consequences still have not disappeared, it is possible to do that, however, if the child does not sleep, feels anxiety, fear, it is rather complicated to establish the connection between the taken actions and the consequences, because in such case the influence of other factors will have to be eliminated as well: such indications may arise due to stress, for example, the divorce of his parents, the loss of a close person, the change of environment and the like. In addition, in the case of every experienced aggression the child also experiences a psychological aggression the influence of which is rather difficult and sometimes impossible to establish.

In the definition of aggression, purposefulness or intention to harm is usually emphasized as essential when distinguishing aggressive actions from non-aggressive (Berkowitz, 1989). Actions that have no intention to harm other person are not aggressive, even in such case, when they cause the same harmful consequences as aggressive ones. When examining parents actions against their child, we would detect their intent to harm their child extremely rarely. Here aggression that in psychology is called instrumental is usually found (Fanti, Frick, Georgiou, 2009; Ollendick et al, 2009), which manifests itself not in a malignant intention to harm or protective reaction towards danger, but is applied as a remedy to reach a goal, when the aim is neutral or even positive: aggression is used in order to educate the child.

When identifying actions as aggressive, the criterion of harm could be essential, however the harm incurred by the child is not always noticeable at once or it can manifest in a latent, unpredictable way, or later in the behaviour of the adult (Gershoff, 2002; Miller-Perrin, Perrin, Kocur, 2009), therefore it should be necessary to evaluate not only consequences established objectively, but also a possibility to harm. Some authors, when distinguishing aggressive actions, tend to emphasize not only the caused harm, but also to evaluate the threat of causing harm to the child (Straus, Gelles, 1990). The character of taken actions, intensiveness, maturity of the child and other circumstances in every particular case can be always different for consequences to occur, therefore, when evaluating the actions taken by parents 
against the child, probability for harm to occur should have to be sufficient condition to identify them as aggressive.

When summarizing, it has to be maintained that due to complexity and versatility of researches of the phenomenon of aggression itself, conceptual definition of the victim gets a relative meaning and becomes debatable when there is an attempt to apply it to a particular situation. In defining aggressive parental actions towards their child the criterion of intention to harm is not usually urgent, whereas the criterion of harm caused by aggressive parental behaviour should include both harm and the threat to harm the child.

\section{Educational prerequisites for prevention of aggressive parental behaviour with their children}

The upbringing of children in the family depends on the point of view regarding the child and the attitudes of parents which most often are based on personal experience (Simons, Wurtele, 2010). The aggressive experience of parents in the childhood determines that positive relationship with the child is not always maintained in the educational attitudes of parents, which in its turn influences their aggressive behaviour (Borse et al., 2008; Protect the ones..., 2012). The dominant aggressive behaviour in educational attitudes is transmitted from generation to generation (Doak, 2007). Thus, parents do not sufficiently value the importance of themselves as the teachers of future parents. The acquired model becomes an essential orientation when implementing father's/mother's role even when a person seeks to refute the acquired model: he/she tries not to treat his/her child in the same manner as their parents treated them (Kaučikienè, Švedaitė-Sakalauskienė, 2007). Here a special parental responsibility for their transmission of a behaviour model to their children and through them to other generations becomes apparent.

Aggressive parental behaviour with their children is first of all an educational problem, because the relationship of the parent and the child is the relationship between the educator and the educated, therefore it has an educational element, whereas it becomes a psychological, legal or medical problem later on, when corresponding consequences arise: an infringement of the rights of the child, a physical or mental injury of the child and the like. Interaction between parents and the child is examined as a prerequisite for prevention of aggressive parental behaviour and prerequisite for prevention of the experience of expressions of other aggressions and as a prerequisite of successful development and adaptation in life and mental health.

Mutual influence is characteristic of parents and the child relationships, however first of all the character of the relationship depends on the parents' attitude towards themselves when performing father's/mother's role, attitude towards the child as a participant of interaction, attitude towards family as a constantly changing system the successful functioning of which is guaranteed by the possibility of a personal satisfaction, self-expression and self-actualization of every member of the family. Whether the relationship between parents and the child will be based on communication creating personality and will become an educational interaction, depends on the form and content of the communication. Interaction is also called a partnership relationship (Aramavičiūtè, Martišauskienè, 2008), and that means that both the adult and the child are equal when it comes to their value and dignity. Equivalence of parents and the child does not deny the importance of parents as upbringing authority and does not belittle its educational power. On the contrary, improvement occurring due to interaction is possible only then when interaction is based on mutual respect and recognition of dignity.

Human life and dignity are inseparable values, therefore they cannot be understood separately (Spruogis, 2002). Dignity is the condition of humanness, therefore we would negate his humanness at the same time, if we do not recognize person's dignity. The dignity of every human is an absolute, unchanging value which cannot be lost because of attitude or actions of people, but which can be violated (Venckienè, 2008). Dignity reflects equal value of all people and at the same time recognizes 


\section{Int. Conf. SOCIETY. HEALTH. WELFARE.}

exclusiveness, uniqueness, individuality of every person, therefore, if we do not recognize the difference of another person, we would violate his dignity. The category of dignity does not need to be given grounds or to be substantiated, but only needs to be recognized and respected. The essential condition of harmonious coexistence of the family, that is the fundamental social structure of society, is the recognition of unconditional value and dignity of every member of the family, including the child as well (Kairienè, 2010).

The recognition of child's value and dignity is limited by erroneous apprehension of value when child's value is measured by the years he/she lived, acquired knowledge, accumulated experience or added value: being the child, he/she is only the source for investment which who knows when will give returns, therefore he/she is not worth respecting. It is even worse, when the child who is not respected, is demanded to show respect. Differentiation between participants of interaction and education that is not based on giving example and authority denies any possibility to educate. The recognition of another person's dignity the most important condition of human relationships, therefore it cannot be applied with reservations. The recognition of the child as an equal participant of interaction is not only a necessary condition of the recognition of his/her humanness, but a prerequisite for his/her successful socialization and (self-)education.

\section{Psychosocial prerequisites for prevention of aggressive parental behaviour with their children}

Empowerment is giving powers, activation, and stimulus to act relying on inner and outer resources. Child empowerment as preventive prerequisite of aggressive behaviour towards him manifests itself in various senses. In a legal sense it creates possibilities to actively realize the role of the possessor of rights and implement the right to participate. In an educational sense it creates prerequisites for child's (self-) education and self-expression when developing his/her self-dependence and responsibility. In a psychosocial sense it creates prerequisites for positive relation towards himself/herself and environment and its expression. Child empowerment can be applied by involving the child into preventive activity on all levels of prevention. During the primary stage of prevention empowerment covers the knowledge of the phenomenon of aggression, i.e. the supply of the information about the phenomenon, the relationship of the child and the adult, the rights of the child and prerequisites for their implementation with emphasis on the adult's responsibility for the relationship with the child and the possibility to resort to the help. During the secondary stage of prevention the purpose empowerment is linked to rendering him/her help as much as it is possible by involving him/her into protection process through active participation in witnessing, helping to find out his/her needs and interests and establishing the possibilities to render help. Tertiary prevention is linked to activation of the child in order to resist a possible recurrence of aggression.

When rendering help to the child who has experienced or experiences aggression in the family, it is necessary to evaluate any actions by taking into account child's interests. It is well worth to analyze preventive help regarding the implementation of child's interests in three ways: firstly, by evaluating whether due to intended actions to render help child's interests will not be infringed, for example, whether the child will not experience secondary victimization during the process of his/her protection, secondly, whether actions that are taken are in line with the best child's interests at the present time, i.e. whether, when making decisions that are related to the event, the participation of the child is guaranteed, thirdly, by foreseeing whether preventive actions are in line with his/her interests in the future perspective. The interest of every person coincides also with their (self-) education purpose which in the broad sense can be identified as self-expression and may manifest itself in various areas of life. General prerequisites as positive evaluation of himself/herself and others, strong social ties, responsibility, adequate evaluation of environment and events and constructive solution of problems and the like are considered as necessary conditions for favourable person's self-expression.

$$
\text { 00015-p.5 }
$$




\section{SHS Web of Conferences}

Two preventive directions of aggressive parental behaviour with their children are distinguished: one is directed at destroying or decreasing of influence of the factors influencing phenomenon, the other is directed at the search of protective factors and the increase of their influence. One of the aspects of the implementation of the rights of the child is linked to the possibility of child himself/herself to actively use his/her rights and protect them. The empowerment of the child creates prerequisites to implement the role of the child as an active possessor of rights.

When rendering help to the child, there are three significant sides of prevention: the child who experienced aggression, the father/mother who performed aggressive actions and the family as the system. The most important condition of the prevention regarding the child who experienced aggressive parental behaviour is to restore the functioning of the family and constructional relationship of interaction between family members in order that the child would be able to remain in the family or return to the family that would preserve coordinated existence and would be able to be evaluated as the most favourable environment for the child to grow and develop.

Preventive activity, especially when working with children, should not be limited to information events like lectures, it is important to rear psychological resilience, self-assurance, ability to make independent decisions and the like abilities (Davidson, 2001). The examination of the style of explanation of the events (Seligman, 2006) and the change of child's attitude towards the events towards optimistic direction create preventive prerequisites for formation a positive relationship towards himself/herself and the environment by empowerment of the child through the expression of selfconsciousness and self-esteem. Rearing of self-assurance and self-esteem are related and supplementing each other: rearing of self-assurance creates prerequisites for self-esteem to arise and vice versa.

The possibilities of child empowerment lie in the constructs of support, creation or expansion of his/her social network. The help to a person who got into a problematic situation begins with finding out person's social network (Pierce, 1997), by distinguishing those that render support who are also called help sources that make up social network: family, friends, different institutions that render services, neighbours, colleagues, certain organizations, members of the group to which the man belongs (Winemiller, 1993). The authors underline the quantitative parameter of social network: the more people are there in the network, the more various roles they perform, the greater probability is to get help (Pierce, 1997). Thus, social activity of the child due to which social ties are made can be regarded as the factor not only of help, but also as the factor to elucidate aggressive behaviour with the child.

Another important preventive prerequisite to empower the child is the supply of the information about the events connected with the child by applying the model of factual knowledge. Informing about negative aspects of the phenomenon creates possibilities to empower the child to change his/her relation towards the event from passive to active. When the child is given the information, there is expectation that automatically his/her attitude will change and the behaviour will change correspondingly. The supply of information in order to empower the child manifests itself in three aspects. Firstly, the supplied information after turning into knowledge changes the attitude of the child towards himself by decreasing the "deposit" of guilt regarding the event, by decreasing helplessness, by increasing self-esteem; when it comes to the offender, - by understanding the role and responsibility of the adult; when it comes to the situation, - by understanding that the situation is temporary, by understanding the possibilities to rule and change the situation. Secondly, due to the change of attitude the possibility arises not only to solve the particular problem, but to take part actively in the process of their own protection. Thirdly, empowerment creates preventive prerequisites to decrease person's victimization.

\section{Conclusions}

Combined attitude towards aggressive parental behaviour with their children is based on three categories of prerequisites for prevention: legal, educational and psychosocial. Legal prerequisites are linked to the establishment of the criteria of aggressive behaviour: intention to harm and harm itself that determine 


\section{Int. Conf. SOCIETY. HEALTH. WELFARE.}

the status of the child victim and the possibilities to help him. Specificity of the relationship of parents and the child determines that the intention to harm is not always urgent, therefore cannot always be essential, whereas the criterion of harm should include and establish harm and the threat of harming the child. Educational prerequisites are based on the interaction of parents and the child which is always educational, hence it has to be based on equality of the participants of the interaction and respect to person's dignity as an absolute value, only then possibilities for successful socialization and (self-) education of the child will be created. Psychosocial prerequisites are discerned in the empowerment of the child, and that is possible on all the levels of prevention in order to use possibilities of the child to participate when implementing and defending his own rights and interests by encouraging the knowledge of the phenomenon, changing his relation towards the event, witnessing, helping to find out his/her needs, using the social network to support the child and resisting secondary and repeated victimization.

\section{References}

[1] Annerbäck, E. M., Sahlqvist, L., Svedin, C. G., Wingren, G., Gustafsson, P. A. (2012) Child physical abuse and concurrence of other types of child abuse in Sweden - Associations with health and risk behaviors. Child Abuse \& Neglect, 36 (7/8), p. 585-595

[2] Aramavičiūtè, V., Martišauskienè, E. (2008) Santykiụ su tėvais pokyčiụ aspektai: paaugliụ požiūris. Acta Paedagogica Vilnensia, 20, p. 204-212

[3] Berkowitz, L. (1989) Frustration-aggression hypothesis: Examination and reformulation. Psychological Bulletin, 106, p. 59-73

[4] Borse N. N., Gilchrist J., Dellinger A. M., Rudd R. A. Ballesteros M. F. Sleet D. A. (2008) CDC Chilhood Injury Report: Patterns of Unintentional Injuries among 0-19 Year Olds in the United States, 2000-2006. Atlanta (GA): Centers for Disease Control and Prevention, National Center for Injury Prevention and Control

[5] Brock, D. W. (2005) Shaping Future Children: Parental Rights and Societal Interests. The Journal of Political Phylosophy, 13 (4), p. 377-398

[6] Convention on the Rights of the Child (1989) General Assembly resolution 44/25 of 20 November

[7] Davidson, J. (2001) The sex exploiter. Theme paper for the Second World Congress Against Commercial Sexual Exploitation of Children. Philadelphia

[8] Doak, M. J. (2007) Child abuse and domestic violence. London: Thomson

[9] Fanti, K. A., Frick, P. J.,Georgiou, S. (2009) LinkingCallous-Unemotional Traits to Instrumental and Non-Instrumental Forms of Aggression. Journal of Psychopathology \& Behavioral Assessment, 31(4), p. 285-298

[10] Finkelhor, D., Ormrod, R., Turner, H., Hamby, S. (2012) Child and Youth Victimization Known to Police, School, and Medical Authorities. National Survey of Children's Exposure to Violence. Juvenile Justice Bulletin. Office of Juvenile Justice and Delinquency Prevention

[11] Freeman, M. D. A. (2010) Upholding the Dignity and Best Interests of Children: International Law and the Corporal Punishment of Cildren. Law \& Contemporary Problems, 73 (2), p. $211-$ 251

[12] Gershoff, E. T. (2002) Parental corporal punishment and associated child behaviors and experiences: A meta-analytic and theoretical review. Psychological Bulletin, 128, p. 539-579

[13] Hundeide, K., Armstrong, N. (2011) ICDP Approach to Awareness-Raising about Children's Rights and Preventing Violence, Child Abuse, and Neglect. Child Abuse \& Neglect: The International Journal, 35(12), p. 1053-1062

[14] Kairienè, B. (2010) Orumo kategorija bausmės koncepcijoje. LOGOS, 65, p. 144-153

[15] Kaučikienė, J., Švedaitė-Sakalauskienė, B. (2007) Tėvo vaidmuo probleminèse šeimose: kokybinè analizè. Socialinè teorija, empirija, politika ir praktika, 4, p. 104-115 
[16] Miller-Perrin, C. L., Perrin, R. D., Kocur, J. L. (2009) Parental Physical and Psychological Aggression: Psychological Symptoms in Young Adults. The International Journal, 33(1), p. 111

[17] Noh, C. H. C. Wan Talaat, W. I. A. (2012) Verbal Abuse on Children: Does It Amount to Child Abuse under the Malaysian Law? Asian Social Science, 8 (6), p. 224-228

[18] Ollendick, T. H., Jarrett, M. A., Wolff, J. C., Scarpa, A. (2009) Reactive and Proactive Aggression: Cross-informant Agreement and the Clinical Utility of Different Informants. Journal of Psychopathology \& Behavioral Assessment, 31(1), p. 51-59

[19] Pierce, G. (1997) Sourcebook of social support and personality. New York; London: Plenum Press

[20] Pritchard, C. (2004) The Child Abusers: Research and Controversy. Buckingham: Open University Press

[21] Pritchard, C., Sayers, T. (2008) Exploring potential extra-family child homicide in the UK and estimating their homicide rate: Perception of risk and the need for debate. British Journal of Social Work, 38, p. 290-307

[22] Pritchard, C., Williams, R. (2010) Comparing Possible 'Child-Abuse-Related-Deaths' in England and Wales with the Major Developed Countries 1974-2006: Signs of Progress? British Journal of Social Work, 40, p. 1700-1718

[23] Protect the ones you love: Child Injures are Preventable (2012) http://www.cdc.gov/ SafeChild/Fact_Sheets/Overview-Fact-Sheet-a.pdf

[24] Sagatys, G. (2008) Ivaikinimo teisinio reguliavimo problemos Europos žmogaus teisiụ teismo jurisprudencijoje. Jurisprudencija, 2(104), p. 18-27

[25] Seligman, M. E. P. (2006) Learned Optimism: How to Change Your Mind and Your Life. New York: Vintage books

[26] Shapiro-Mendoza, C. K., Kimball, M.; Tomashek, K.; Blanding, S. (2009) US infant mortality trends attributable to accidental suffocation and strangulation in bed from 1984 through 2004: Are rates increasing? Pediatrics, 123, p. 533-549

[27] Simons, D. A.,Wurtele, S. K. (2010) Relationships between parents' use of corporalpunishment and their children's endorsement of spanking and hitting other children. Child Abuse \& Neglect, 34(9), p. 639-646

[28] Spruogis, E. (2002) Šiuolaikinès demokratinès valstybès socialinè paskirtis ir funkcijos. Vilnius: Lietuvos teisès universitetas

[29] Straus, M. A., Gelles, R. J. (1990) Physical violence in American families: risk factors and adaptations to violence in 8,145 families. New York: Transaction Publishers

[30] Summary of the Report of the independent Expert for the United Nations Study on Violence Against Children, A/61/299 http://www.crin.org/docs/VAC_Summary.pdf

[31] Uscila, R. (2003) Nusikaltimo aukos ir nusikaltèlio interakcija: viktimologinis aspektas. Vilnius: Lietuvos teisès universitetas

[32] Venckienè, E. (2008) Žmogaus orumas kaip teisine kategorija. Vilnius: Mykolo Romerio Universitetas

[33] Weber, M. A., Ashworth, M. T., Risodon, R., Sebire, N. J. (2009) The role of the post-mortem investigations in determining the cause of sudden unexpected death in infancy. Archives of Childhood Diseases, 94, p. 170-181

[34] Winemiller, D. (1993) Measurement strategies in social support: a descriptive of literature. Journal of Clinical psychology. New York 